UDC: 339.138 .

JEL Classification M21, M31

Liudmyla Alaverdian

Ph.D in Economics, Associate Professor of the Department of Commodity and Commercial Activity in Construction, Kyiv National University of Construction and Architecture,

(Kyiv, Ukraine)

Olesia Romanenko

Ph.D in Economics, Associate Professor of the Department of Commodity and Commercial Activity in

Construction, Kyiv National University of Construction and Architecture

(Kyiv, Ukraine)

\title{
MODERN MARKETING TOOLS AND INTERNET TECHNOLOGIES IN UKRAINIAN BUSINESS IN THE FORMATION OF MARKETING STRATEGIES
}

Research of modern marketing strategies used by business in the Ukrainian market of goods and services, in the context of the process of digitalization is a topical issue. The article reveals and summarizes the components of successful marketing strategies and tools of modern marketing in Ukraine, which should be used by business in a changing environment and existing risks, taking into account the concept of social responsibility. A high-quality research method was applied on social Internet networks, an in-depth interview was conducted, including a survey of 30 key informants representatives of small and medium enterprises.

Key words: marketing strategy, marketing tools, Internet technologies, business entities, Internet marketing, marketing trends.

\section{DOI: 10.15276/mdt.4.4.2020.7}

Statement of the problem in general form and it's connection with important scientific or practical tasks. New trends and approaches in marketing appear annually, quarterly and even monthly, changing the way to attract potential buyers, the interaction between sellers and buyers, as well as the promotion of goods and services in the market and more. And to succeed in such a changing environment, we need to anticipate such changes due to the fact that high sales of goods and services today do not guarantee the level of their preservation in the future. Therefore, the business must constantly monitor new trends in marketing activities to keep up with what is happening in the market.

Properly chosen marketing strategies and tools allow a business to monitor how its customers make purchases, research products and services not only their own but also competitors. Based on this information, the business is able to keep abreast of changes not only in consumer behavior, but also in determining their priorities. In addition, businesses should clearly understand their target audience and its expectations from the goods (services) sold (provided). Thus, by responding quickly to changes in the market of goods and services, businesses will be able to remain competitive and relevant in their segment of the target market in the short and long term. And this is possible only through an understanding of Internet marketing methods and the use of its effective tools in the activities of small and medium enterprises.

(C) 2020 The Authors. This is an open access article under the CC BY license (http://creativecommons.org/licenses/by/4.0) 
Analysis of the latest research and publications, which initiated the solution of this problem and on which the author relies. The close attention of scientists and practitioners to the study, implementation, analysis of marketing tools and Internet technologies in the domestic and foreign business world is due to the fact that the Internet today is a global electronic market where you can not only communicate but also perform various purchasing transactions-sale goods, advertise brand and company, make payments [1]. In [2] the differences between the concepts of Internet marketing and digital or digital marketing are considered. Issues related to the study of the formation and development of Internet marketing are highlighted in many works of such scientists as Ilyashenko S.M., Shipulina Yu.S., Smolyar Yu.Yu., Bagatskaya K., Geidor A., Verby V.A., Fostolovich V.A., Ustenko M.O., Ruskikh A.O. and etc. [3, 4, 5, 6, 7]. And practitioners test, analyze, improve and highlight the results of their work $[8,9,10,11]$.

Highlighting the previously unresolved parts of the general problem to which the article is devoted. According to the literature, digitalization processes are actively taking place in Ukrainian business, and in order to be competitive, business entities must constantly monitor the most important changes taking place in a changing marketing environment. However, we consider it expedient to generalize the developed theoretical material and combine it with the conclusions of experts who directly apply modern marketing tools and Internet technologies in practice so that the highlighted results can be used by businesses in shaping their marketing strategies.

Formulation of the purpose of the article (statement of the problem). The aim is to identify and summarize modern digital marketing tools and Internet technologies that have been tested in practice and should be used in business in the development of marketing strategies taking into account the concept of social responsibility.

Statement of the main material of the research with full justification of the scientific results obtained. General marketing tools apply to almost any type of business, regardless of its size. They help to effectively reach the target audience, improve conversions, ie create the conditions for the user to perform a particular action, for example, order a product and convert more potential customers from customers through marketing content. The most successful, effective, and most importantly, tested by business, in practical use of Internet marketing tools are presented in Fig. 1.

Before revealing in more detail the essence of each of these methods of Internet marketing and show their importance in determining marketing strategies by small and medium enterprises, it should be noted that the tool SMM (Social Media Marketing) is the most common and effective. Its popularity and effectiveness is due to the ease of tracking the target audience on social networks depending on their interests, hobbies, age; the possibility of creating a community to inform visitors about various innovations; ease of collecting traffic due to the adaptability of social networks for mobile phones.

Search engines use SEO-optimization tool to monitor the ranking of their own website, which helps to make the brand more popular, increase sales and, consequently, increase profits for companies. As a result of site promotion, the audience begins to trust the Internet resource, which appears on the first pages of the issue, and the number of customers increases if the site is filled correctly.

With the help of banner advertising - animated images with advertising text and hyperlinks to the advertiser's site, flickering and, as a rule, occupy most of the screen, you can effectively convey to the target audience information about the product.

Contextual advertising is no less effective tool of Internet marketing, because thanks to it the user who is interested in your product or service is attracted himself, regardless of the service. 


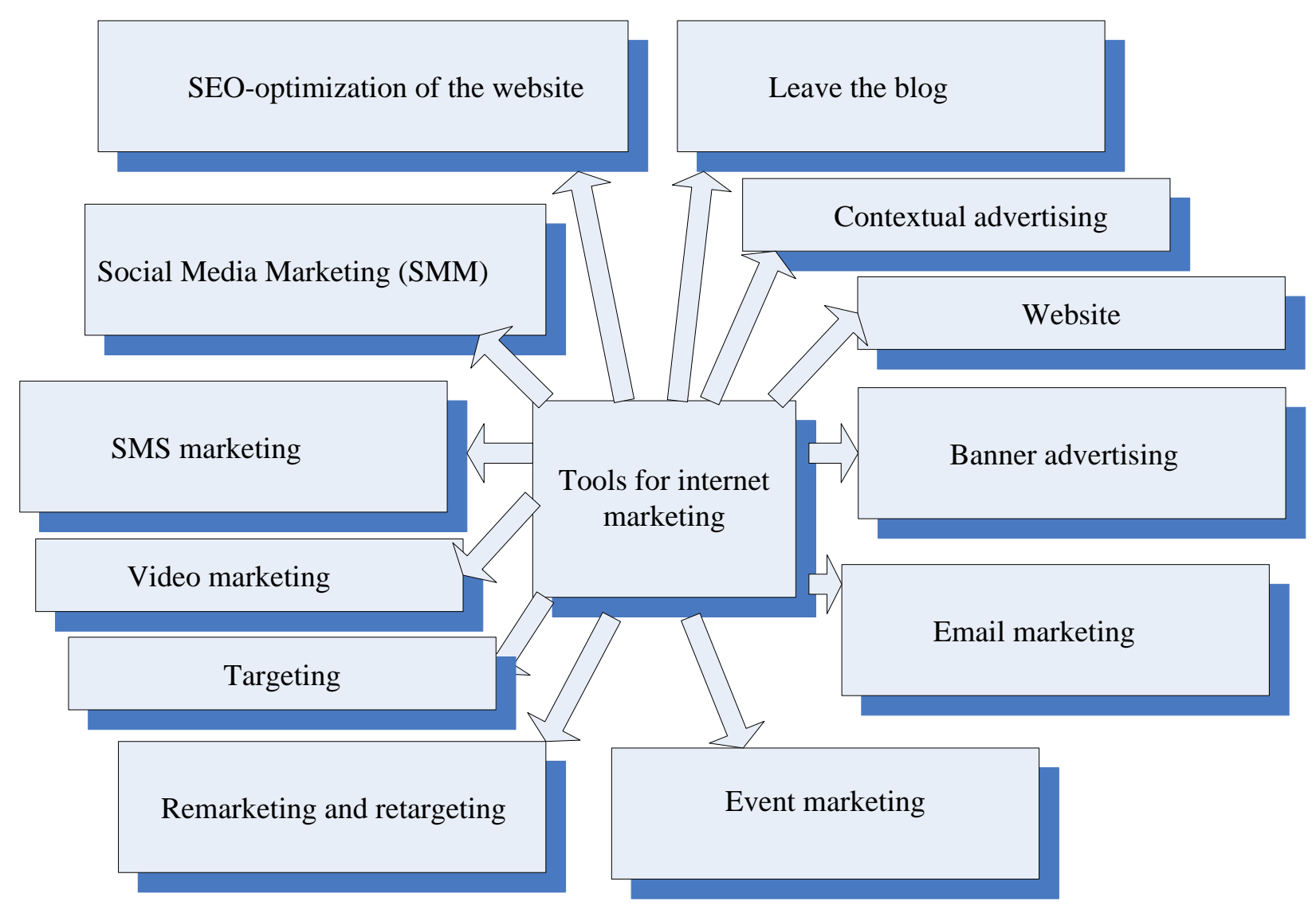

Figure 1 - Internet marketing tools

Establish and track feedback between the entrepreneur and the consumer is very effective and economical with e-mail marketing, the essence of which is that each customer individually receives electronic messages about the results of the company, the arrival of new products in the online store, start of shares or other companies.

A similar advertising tool with e-mail marketing is SMS marketing. But mailings are made by SMS and only to those users who are waiting and agree to receive such messages. There can be no or minimal spam here, as cellular operators are actively fighting it. The most effective mailing is the one made during the loyalty program and provides for the use of discount or bonus cards directly by customers who are interested in goods or services of the company, fill out special questionnaires and agree to receive mailings by SMS and, if desired, by e-mail.

With the use of an Internet marketing tool such as blogging, having a convenient platform for communicating with the audience and receiving feedback, you can unite users in thematic unions, publish and update information about the company or products, find new consumers.

The effectiveness of video marketing is due to the fact that visual content is always easier to perceive than a large text block, and the ease of creating a video and distributing it via e-mail or posting on Youtube video hosting makes this tool effective. You can also upload small videos to Instagram, which can effectively promote the online store with their help, because the video itself helps to better understand the features of a product, the order sequence, and so on.

Remarketing and retargeting are contextual advertising that is shown to users who have already visited the company's website. In other words, the online store in which retargeting is configured will remind the user of the previous choice by constantly showing links on any online resource. 
Product promotion through events such as webinars, forums, seminars is called event marketing or event marketing. As a result, emotional contact is established between the consumer and the brand, the customer receives all the necessary information about the product or service. Also very common now is integrated Internet marketing, which is the use of several tools at different stages.

Analysis of marketing tools shows a decrease in the effectiveness of outbound marketing (active marketing strategy, covering potential customers) and increasing the role of inbound marketing (passive strategy, which attracts the audience with prospects). Inbound marketing requires quality from entrepreneurs, the value of content adapted to the needs of the target audience and customers. And attracting customers as marketers and promoters allows businesses to make the process of buying goods interesting for consumers and thus increase sales (Fig. 2).

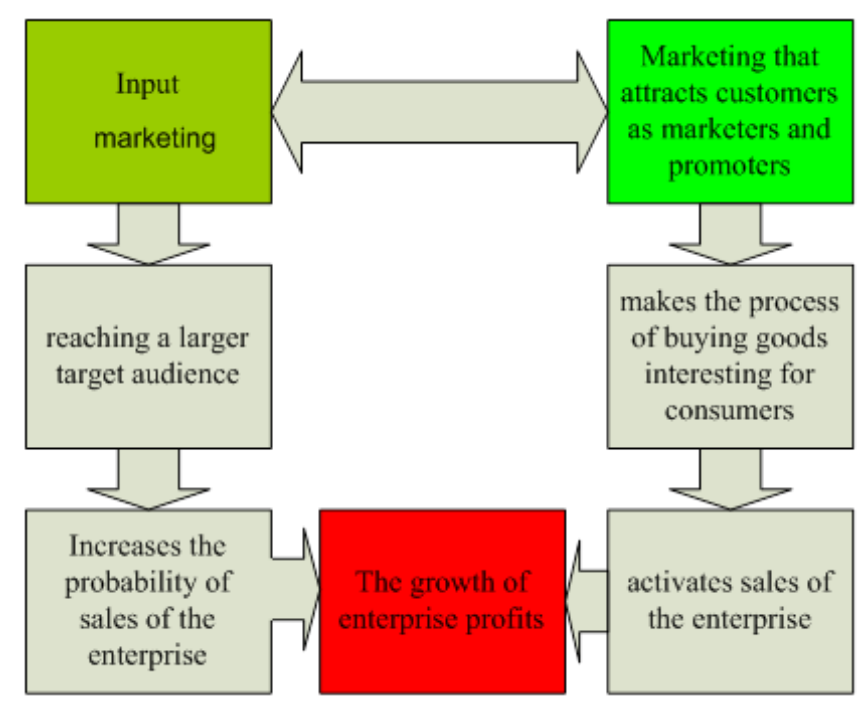

Figure 2 - Key features of inbound and outbound marketing

Recently, much attention has been paid to research and creation of marketing funnels in business $[9,10]$. However, we believe that the main disadvantage of this model is its one-sided direction: after all, customers are not in the first place and after they pay for the goods companies "forgot" about it for a time equal to their repurchase. Therefore, currently the "marketing funnel" scheme is gradually being replaced by the "Wheel" scheme, which pays special attention to customer service (Fig. 3).

The "wheel" scheme illustrates the process, with an emphasis on the fact that excellent service is a marketing strategy. It follows that business, first of all, should pay special attention to customer service, and therefore train their employees in this process, equipping them with tools for processing requests and solving problems, and this, in turn, will allow customers to promote and protect business through their own networks, both online and in person.

Our survey of Ukrainian consumers during the quarantine campaign to prevent the spread of coronavirus COVID-19 found that $47 \%$ of buyers view three to five items of content before contacting a sales representative, and $70 \%$ of people prefer learn about new products through content, not through traditional advertising. That is why we believe that businesses need to pay attention to the type of content that resonates most with the person of its buyer, target audience and current customers. And to increase the efficiency and accessibility of marketing efforts of business, it is advisable in today's conditions to create and distribute video content to communicate with your audience. 

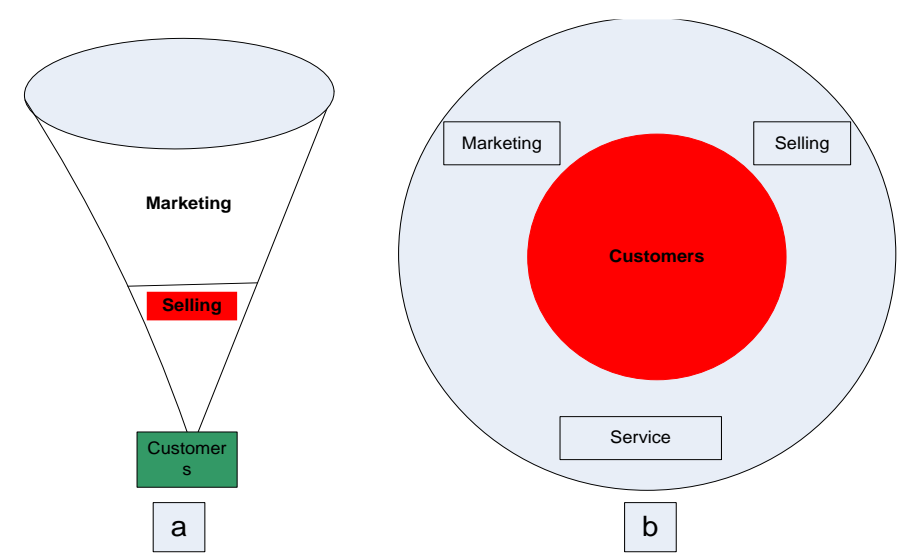

Figure 3 - "Marketing funnel" (a) and "Wheel" (b) schemes

Yes, the effectiveness and popularity of video marketing has increased many times in recent times: $83 \%$ of small and medium-sized businesses believe that video is a good return on investment, and more than $50 \%$ of consumers say they like video content more than any other type of content . That's why video is a valuable addition to sales and customer service. Moreover, due to the cheapness of its creation and distribution, you can more often include video in marketing strategies.

In order to attract a new audience that the business has never encountered before, native advertising is widely used, which differs from the "traditional" by increasing the probability of its viewing by consumers, because native advertising is $50 \%$ more often than banner advertising. Examples of native advertising can be found on social networks, in search results, on platforms for content recommendations, for example, links to other content at the bottom of the page, offering to learn more about the topic or related to it.

Quite widespread social networks in the world strengthens the role of marketing in social networks, which has recently become a very popular trend, and therefore has taken a leading place in the marketing strategy of almost every business [11]. Social media marketing allows businesses to communicate with their own audience in person, making the brand more human.

Observations of the process of cooperation between small and medium-sized businesses and micro-influencers - promoters in social networks - have also made a significant contribution to boosting sales of business structures and increasing their brand awareness. By choosing an influencer, business is no longer limited to big celebrities and well-known people. In fact, micro-influencers have found their niche in the world of social networking and have begun to play an important role in converting leads, establishing contacts with the audience and increasing brand awareness. They have fewer followers than celebrities, usually from a few thousand to tens of thousands of subscribers, but despite this, their posts often provide more opportunities due to a higher level of involvement. In addition, they are considered "ordinary" or "ordinary" people as opposed to hard-to-reach celebrities, the audience perceives microinfluencers more as friends and family members and, therefore, more likely to trust their opinions and recommendations. If, for example, an influencer is popular on Instagram and has about 500,000 followers interacting with her posts, then 50,000 likes give such an influencer $10 \%$ involvement. It is through these indicators that micro-influencers can be seen as the future promotion of goods and services through opinion leaders. At the same time, the number of followers always looks attractive, but it is really necessary to determine their impact, which is related to the level of involvement: clicks, subscriptions and purchases, and so on. 
One of the effective technologies to improve interaction with customers in the interests of business in the choice of marketing strategies is the use of virtual and augmented reality (VR and AR, respectively) [12].

Virtual reality is a computer-generated realistic scenario, and augmented reality is a real world complemented by tactile, olfactory, or visual additions. VR and AR are different experiences, but both realities are extremely important in the world of marketing. For example, a panoramic video on Facebook is VR, and the IKEA PLACE program from IKEA, which helps to visualize the furniture in the room - AR.

Virtual and augmented realities are used to complement and improve customer service both online and offline. The introduction of this trend by business is limited by the high cost of equipment, and higher education institutions that prepare bachelors and masters in "Marketing" and "Information Technology" actively include the study of virtual and augmented reality in modern educational programs. Moreover, with the rapid development of information technology, it is likely that in the near future VR and AR applications will become more accessible, and therefore companies will be able to add these technologies to their marketing strategy without hindrance, both technically and financially.

In the conditions of formation and rapid development of the market economy, it has happened that data are of great value in the world of marketing. More than two centuries ago, the English banker, businessman and financier of Jewish descent Nathan Rothschild said: "Who owns the information - he owns the world" [13]. The popularity and success of the Rothschilds "engraved" these words in the minds of millions of representatives of completely different professions. Therefore, data, be it an email address, credit card information or smartphone location, etc. is very valuable. And the one who owns them is not only responsible for them, but also has privileges, because any business works with data. It is the lifeblood of everything related to marketing, sales, service and more. Therefore, in order to look like a reliable company and not to "exploit" its customers, it is necessary to develop and widely use effective mechanisms to ensure the control of their customers over their data.

According to research by GfK Ukraine, users of the Ukrainian segment of the Internet in $85 \%$ of cases get acquainted with the privacy policy of the Internet resource they visit [14]. More than $30 \%$ of users are aware of the existence of cookies and are fairly familiar with the mechanism of their operation. At the same time, more than $54 \%$ of survey participants confirmed that they did not have enough knowledge to manage them, and $22 \%$ of respondents said that they had carefully read the information on personal data protection on the GfK Ukraine website.

Thus, the awareness of domestic users of the Internet segment is gradually increasing regarding the requirements of the legislation on personal data protection, the rights of users to privacy and the ways guaranteed by law to demand the restoration of their violated rights. This, in turn, increases the risks of companies that conduct research on the Internet. Therefore, according to the General Regulation on Personal Data Protection, modern organizations must ensure that their data is collected legally and securely, and that those who collect and manage this data must protect it and respect the rights of consumers.

Businesses should take into account that due to the difference between social networks from one another, the effectiveness of content types differs on different platforms. Therefore, both one-day (short-term) marketing on social networks and permanent (long-term) content must be used depending on the type of platform used by the company to promote its products and services.

An example of one-day marketing is Story on Instagram and Facebook. Storiz is a photo and video that is covered for 24 hours and then disappears and stored in the "archive". Nowadays, Instagram is gaining more and more popularity, and for the user the behavior of the 
story is playful, relaxed, with an advantage towards fast content and intensive use of UX functions (gifs, boomerangs, polls, etc.). The instantaneous function is not the only differentiating factor. Instagram pages can also be edited using filters, GIFs, color text, etc. These fun additions require brands to brand new strategies for producing and publishing oneday content that is different from other content on their social networks.

The constant content on social networks is arranged differently: photos on Instagram are stored for a long time, but it is important for brands to do everything on time, because no one wants to see messages related to Easter, when it is long overdue.

The fact that Instagram users are more active on weekdays, during the working day, suggests that they look there to take a break! It is very important to practice your brand voice and have a certain point of view, as well as to understand what exactly you can do business for your audience during this break to promote your products and services. It may be inspiring posts, or informative, fashionable, playful or just beautiful walls of the company's profile on Instagram, but the message must correspond to the main message of the brand.

Improved search engine optimization (SEO), which allows to increase the Internet presence of the company's website and therefore helps the business to become more accessible on the Internet, should be in high demand in the marketing strategy of any modern enterprise that produces or sells goods. Implementing voice search allows users to get answers to their questions, as consumers have been using Siri, Alexa, Cortana or Google Assistant very often lately. These digital assistants not only respond to short information requests, but also handle local, conversational and individual needs.

Based on this, businesses that aim to apply a marketing strategy using SEO tools should improve search types and change the way they present information: instead of using Google's manual search algorithm, optimize their content based on questions. This approach will allow users to get the answers they need. They can ask questions aloud, and get a quality and accurate answer, performing multiple tasks at once, saving their time.

The implementation of business voice search tactics involves the following steps:

First, the organization should look at the topic and determine what questions users can ask on this topic. Develop a subtopic plan and find opportunities to insert questions into headlines, which will allow voice assistants to easily recognize content as a solution to a problem.

Second, organizations should use snippets, which are short textual information that Google provides when previewing when users search for definitions or ask questions. In this case, voice assistants usually receive answers directly from the fragments.

Thirdly, to optimize the organization's website with adaptive design for mobile devices, so that the target audience has access to the site anywhere, because, according to research, $48 \%$ of users start researching the brand on a mobile phone, and clickthrough rate in the first position in Google search results on mobile devices is $31.35 \%$. Consequently, the use of mobile phones is growing rapidly, especially for search queries and research. In this regard, businesses must be able to detect and read their site using a mobile device, including smartphones and tablets. Site speed is also important because Google prefers more effective sites in search results (SERPs).

Small and medium business entrepreneurs need to follow new technologies and use them to their advantage when it comes to marketing. For example, the integration of artificial intelligence to help the target audience and customers quickly and accurately solve their problems. In general, artificial intelligence refers to a subset of computer science that teaches machines to do things that require intelligence and to do them the way humans would. These include tasks such as learning, the ability to see, talk, communicate, reflect, or solve problems. When they are performed by a computer, it is called artificial intelligence. It penetrates deeply 
into our daily lives and tasks: Facebook recognizes and marks a person when a friend's text is sent using Siri, there is an automatic connection to artificial intelligence, and so on.

As humanity tends to increase the use of artificial intelligence, especially as consumers, marketers and companies must respond to this. Therefore, the meaning of artificial intelligence is not to replace people or the need for the human factor, but to improve and expand the ability of business to communicate with the audience, helping them to solve their problems faster and more thoroughly.

It is necessary to take into account the fact that artificial intelligence is incredibly useful in collecting and analyzing data and making decisions based on data. Therefore, it should be included in the marketing strategy to better serve consumers.

It is worth noting that adding to the site of a company that sells goods and provides chatbot services to automate tasks and help customers more quickly is a fairly common task in today's world of marketing and information technology in a rapidly digitalizing environment. More than half of consumers expect an answer to any question about marketing, sales or customer service within 10 minutes. But giving it to people during this time is quite difficult, and the ideal solution to this problem is to use chatbots. They work from a computer program that automates certain tasks, usually by communicating with the user through a dialog interface. Bots can be used thanks to artificial intelligence, which helps them understand complex queries, personalize responses and improve interaction over time. Bots provide a quick and easy solution to problems of all levels of complexity and thanks to them there is no need to work in a chat or have a literal conversation with each other.

Conclusions from this research and prospects for further developments in this area. Modern business in the rapid development of digitalization must constantly monitor the most important changes in the changing marketing environment, choose the right marketing strategies, explore not only the needs and behavior of consumers, but also their own and products and services of competitors. Based on the collected data, it will be possible for businesses to understand their target audience, implement the process of rapid detection of changes in consumer behavior and their priorities, and thus determine real expectations from goods, services and business in general.

The study showed that modern entrepreneurs should pay special attention to customer service, ie apply the "wheel" scheme in practice. As a result of its implementation, customers will be able to promote and protect their business through their own networks, both online and in person. But businesses to actively increase the radius of audience should actively use video marketing, chatbots, native advertising on social networks, combining one-day and permanent content, thereby demonstrating their own individuality and originality. At the same time we should not forget about the understanding of timeliness and combination of advertising with a live audience, the ability to use fast, instant content, the brevity and clarity of which are key characteristics.

Given the widespread use of smartphones by mankind, businesses should not only prefer the use of artificial intelligence, which can control conversations and aggregate data from various data sources, from calendars, knowledge bases, to blog posts and videos, but also design and optimize their own sites for mobile using. This requires an adaptive design, the settings of which will allow the company's website to "respond" and change the design and layout, depending on how users access it - from a computer or smartphone.

Thus, the application of these tools in the marketing strategies of modern business will allow companies to increase sales, develop and remain competitive in their market segment. 
1. Prisakar I. (2015), Internet marketing as a modern platform for business development, Businessinform, no. 12, pp. 333-339.

2. Yudin A. (2016), 10 the most popular internet marketing tools. Marketer, no. 11 (18). URL: https://neilpatel.com/blog/10-online-marketing-tools-you-need-when-starting-a-business/ (accessed: December 7, 2020).

3. Ilyashenko S., Shipulina Y., Smolyar Y. (2020), Digital technologies as a means of increasing the efficiency and transparency of the timber exchange trade. Marketing and digital technologies. vol. 4, no. 3, pp. 23-33.

4. Bagatska K., Heydor A.(2019), Business processes in the digitalization of the economy. Bulletin of KNTEU. no 5, pp. 23-32.

5. Verba V. (April 19-20, 2018), Prerequisites, drivers and consequences of digital business transformation. Strategic imperatives of modern management: coll. materials IV International. scientific-practical conf., Kyiv, pp. 491-496.

6. Fostolovich V. (2020), Formation of modern integrated enterprise management systems with the use of digital technologies. Sciences of Europe. no 50. pp. 70-80. URL: http://european-science.org/wpcontent/uploads/2020/05/VOL-3-No-502020.pdf\#page=70 (accessed: December 7, 2020).

7. Ustenko M., Ruskikh A. (2019), Digitalization: the basis of enterprise competitiveness in the realities of the digital economy. Bulletin of Transport Economics and Industry. no 68. pp. 181-192.

8. Kamerman J. (2020) What is landing page and its Benefits to Your Small Business? Meshlivebuild. URL: http://meshlivebuild.com/what-is-a-landing-page/(accessed: December 8, 2020).

9. What is a sales funnel and how to build it for your business (2018), Ag.marketing, no. 11(20). Available at: https://ag.marketing/shcho-take-voronka-prodazhiv (accessed: December 8, 2020).

10. Sales funnel to increase business efficiency (2020), Kebeta.agency/sales business, no. 08(22). Available at: https://kebeta.agency/sales_business (accessed: December 8, 2020).

11. Shevchuk I., (2018), Social Networks as the main marketing tool for companies - tips for beginners, Nachasi, no. (08)26. Available at: https://innowade.net/podorozh-spozhivacha (accessed: December 8, 2020).

12. Lebedenko S., Korchaga M. (2019), The use of augmented reality technologies in trade and marketing. Effective economy, no. 10. URL: http://www.economy.nayka.com.ua/pdf/10_2019/48.pdf (accessed: December 9, 2020).

13. Who owns the information - he owns the world (2017), Breaking news, no. 06(29). Available at: https://nnovosti.info/articles/hto_volodije_informatsijeju_toj_volodije_svitom-622.html (accessed: December 8, 2020).

14. Kozak V. (2013). "Protection of personal data and privacy rules for research on the Internet". Marketing in Ukraine, no. 3, pp. 49-70. URL: http://uam.in.ua/upload/medialibrary/de7/ de7199d7eeaf41d8582cbff76d2f4368.pdf (accessed: December 8, 2020).

Людмила Алавердян, канд. екон. наук, дочент кафедри товарознавства та комериійної діяльності в будівництві, Київський національний університет будівництва та архітектури (Київ, Україна).

Олеся Романенко, канд. екон. наук, дочент кафедри товарознавства та комериійної діяльності в будівнищтві, Київський наџіональний університет будівнищтва та архітектури (Київ, Україна).

Сучасні інструменти маркетингу та інтернет-технологї̈ в украӥнському бізнесі при формуванні маркетингових стратегій.

Дослідження сучасних маркетингових стратегій, що використовуються бізнесом на українському ринку товарів та послуг, в умовах становлення прочесу діджиталізації $\epsilon$ актуальним питанням. В статті розкрито та узагальнено компоненти успішних маркетингових стратегій та інструментів сучасного маркетингу в Украйні, які мають використовуватися бізнесом в умовах мінливого середовища та наявних ризиків із врахуванням конщепиії соціальної відповідальності. Застосовано якісний метод дослідження в сочіальних 
інтернет-мережах, проведено поглиблене інтерв'ю, включаючи опитування 30 ключових інформаторів - представників малого та середнього підприсмництва.

Ключові слова: маркетингова стратегія, маркетингові інструменти, інтернет-технології, суб’єкти підприємництва, інтернет-маркетинг, маркетингові тренди.

Received to the editor June 9, 2020 